\title{
Nar Kabuklarının Döner Tambur Kompostlama Sisteminde Biyoaktivatör İle Kompostlanması
}

\author{
Kamil Ekinci ${ }^{1 *}$, Cenk Soyöz ${ }^{2}$, Barbaros S. Kumbul ${ }^{1}$, Rıfat Yıldırım³ ${ }^{3}$ Şerafettin Yazıc1 ${ }^{4}$, Hilal Rüzgar ${ }^{4}$ \\ 1* Isparta Uygulamalı Bilimler Üniversitesi, Ziraat Fakültesi, Tarım Makineleri ve Teknolojileri Mühendisliği Bölümü, Isparta, Türkiye, (ORCID: 0000-0002-7083- \\ 5199,0000-0002-7379-7597), kamilekinci@isparta.edu.tr, barbarosskumbul@gmail.com \\ 2 Cenk Soyöz MTF Makine Kimya Otomasyon, Uşak, Türkiye (ORCID: 0000-0001-9221-2382), cnk25@hotmail.com \\ 3 Isparta Uygulamalı Bilimler Üniversitesi, Sütçüler Prof. Dr. Hasan Gürbüz Meslek Yüksekokulu, Isparta, Türkiye (ORCID: 0000-0002-4456-9448), \\ rifatyildirim@isparta.edu.tr \\ ${ }^{4}$ Tunay Gıda San. ve Tic. A.Ş, Erzincan, Türkiye (ORCID: 0000-0002-5030-1202, 0000-0002-8646-3425), \\ s.yazici@tunay.com.tr, hilal.ruzgar@tunay.com.tr
}

(İlk Geliş Tarihi 3 Nisan 2021 ve Kabul Tarihi 27 Haziran 2021)

(DOI: 10.31590/ejosat.908927)

ATIF/REFERENCE: Ekinci, E., Soyöz, C., Kumbul, B.S., Yııldırım, R., Yazııı, Ș., Rüzgar, H. (2021). Nar Kabuklarının Döner Tambur Kompostlama Sisteminde Biyoaktivatör İle Kompostlanması. European Journal of Science and Technology, (25), 318-324.

Öz

Bu çalışma, nar meyvesinin işlenmesi sonrası atık olarak çıkan nar kabuklarının, biyoaktivatör ilavesiyle kompostlaştırma sürecinin, kompostlaşma parametreleri üzerine etkisini belirlemek amacı ile yürütülmüştür. Kompostlaştırma işlemi için $0.38 \mathrm{~m}^{3}$ hacimli egzoz gazı geri dönüşümlü ve otomatik kontrollü döner tambur kompostlaştırma sistemi kullanılmıştır. Denemeler süresince; sıcaklık, $\mathrm{CO}_{2}$ konsantrasyonu, kompost materyali nem içeriği, organik madde miktarı, $\mathrm{pH}$ düzeyi, elektriksel iletkenlik değeri, toplam azot ve karbon değiş̧imleri ölçülmüştür. Deneyler toplam 43 gün sürerken, kompostlaşma aşaması 12, olgunlaşma aşaması ise 31 gün sürmüştür. Biyoaktivatör ilaveli reaktörde $55^{\circ} \mathrm{C}$ sıcaklığa altıncı günde ulaşıldığı ve bu sıcaklığın yaklaşık 0.25 gün (6 saat) korunabildiği tespit edilmiştir. Biyoaktivatör ilavesiz reaktör içerisinde maksimum $60^{\circ} \mathrm{C}$ sıcaklığa ulaşılmış, bu sıcaklığın yaklaşık 1.5 gün korunduğu,55 ${ }^{\circ} \mathrm{C}$ 'nin üzerindeki sıcaklı̆ğı ise sadece 2 gün sürdüğü gözlenmiştir. Organik madde kayıplarının, biyoaktivatör ilaveli ve ilavesiz reaktörlerde, kompostlaşma süreci ve olgunlaşma süreci sonunda sırasıyla; \%59.24-\%14.63 ve \%64.32-\%2.04 olduğu belirlenmiştir. Sonuç olarak, kompostlaşma işleminde biyoaktivatör kullanımının kompostlama performans parametreleri üzerinde bir fark yaratmadığı vurgulanabilir. Bunun yanında, kompost olgunlaşma başlangıcında yapılacak biyoaktivatör ilavesiyle kompostun daha hızlı bir şekilde olgunlaşabileceği belirlenmiştir.

Anahtar Kelimeler: Nar işleme atıkları, Kompostlama, Döner tambur kompostlama, Egzoz gazı geri dönüşümü, Biyoaktivatör

\section{Composting of Pomegranate Peels with Bioactivator in Rotary Drum Composting System}

\begin{abstract}
This study was carried out to determine the effect of composting of pomegranate peels left after processing pomegranate fruit with bioactivator. In the study, $0.38 \mathrm{~m}^{3}$-automatic controlled rotary drum composting system with exhaust gas recycling was used in the composting process. During the experiment, temperature, $\mathrm{CO}_{2}$ concentration, compost moisture, organic matter, $\mathrm{pH}$, electrical conductivity, total nitrogen and carbon changes were measured. The experiments took 43 days, the composting stage was 12 days, and the maturation stage was 31 days. Results showed that the reactor with bioactivator reached the temperature of $55^{\circ} \mathrm{C}$ on the $6^{\text {th }}$ day and maintained this temperature for about 0.25 days ( 6 hours). The reactor without bioactivator reached a temperature of $60{ }^{\circ} \mathrm{C}$, but it was able to maintain this temperature for about 1.5 days and the temperature above $55{ }^{\circ} \mathrm{C}$ was only able to maintain for 2 days. Organic matter losses were determined as $59.24 \%$ and $14.63 \%$ in the reactor with bioactivator, $64.32 \%$ and $2.04 \%$ in the reactor without bioactivator, respectively, at the end of the composting process and maturation process. In conclusion, when the use of bioactivators in

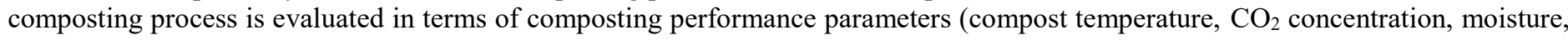
organic matter, $\mathrm{pH}$, electrical conductivity, $\mathrm{C} / \mathrm{N}$ ratio), it can be said that the bioactivator does not make a difference. In addition, it can be said that the addition of bioactivators can be made at the beginning of compost maturation to help the compost mature faster.
\end{abstract}

Keywords: Pomegranate processing waste, Composting, Rotary drum composting, Exhaust gas recycling, Bioactivator 


\section{Giriş}

Nar, ülkemizde genellikle Akdeniz, Ege ve Güneydoğu Anadolu bölgelerinde yetiştirilmektedir. Nar meyvesi, ekonomik getirisi yüksek, ülke çapında yaygın olarak yetiştirilen ve meyve suyu endüstrisinde en çok kullanılan ürünlerdendir. Meyve suyu işleme tesislerine getirilen meyveler hammadde kabulü ile prosese girmektedir. İzleyen aşamada, zedelenmiş meyvelerin ve yabancı maddelerin elenmesi, hemen ardından yıkama işlemi gerçekleştirilmektedir. Y1kanan meyveler, konveyör bant aracılığ 1 ile meyve parçalama bölümüne iletilmektedir. Meyve suyu tesislerinde işlenen meyvelerden proses sonrası binlerce ton nar işleme atığı oluşmaktadır. Meyve suyu tesislerinde oluşan bu atıklar genellikle depolama alanlarına veya araziye dökülmektedir. Atık yönetiminin etkin ve sürdürülebilir olması için atıkların özelliklerine uygun alternatif bertaraf yöntemleri ile değerlendirilmesi gerekmektedir. Meyve suyu prosesinden çıkan bu atıkların homojen yapıda ve diğer atıklarla karışmamış olması, kompostlaştırma için önemli bir avantaj oluşturmaktadır. Bununla birlikte, nar işleme atıklarının yönetiminde bölgesel ve mevsimlik olarak atık potansiyelinin değişkenliği dikkate alınmalıdır (Şevik vd., 2018a).

Kompostlaştırma işlemi ile organik atıklar ayrıştırılarak toprak iyileştirici özellikler taşıyan toprak benzeri bir maddeye dönüştürülmektedir. Özellikle son y1llarda benzer yollarla üretilen kompostun, tarımsal üretimde kullanımı gittikçe yaygınlaşmaktadır. Aynı zamanda kompostlama ile depolama alanlarında saklanması zorunlu olan atık miktarı azaltılmakta ve bu yolla olası çevre problemlerinin önüne geçilmiş olmaktadır. Türkiye'de nar üretimi her geçen yıl artış göstermektedir. Narın işlenmesi sonucu işlenen toplam nar miktarının ağırlıkça yaklaşık yarısı kadar atık oluşmaktadır. Özetle, önemli bir kompost potansiyeli taşıyan nar atıklarının, atık yönetimi ilkelerine uygun olarak toprak için yararlı bir maddeye dönüştürülmesinde çevre güvenliği ve insan sağlığı açısından çok önemli faydaları bulunmaktadır (Şevik vd., 2018a; Kanat ve Ergüven, 2020).

Tarımsal atıkların kompostlaştırılmasında farklı yöntemler kullanılmakla birlikte, döner tambur ile kompostlama, son zamanlarda üzerinde yoğun araştırmalar yapılan bir yöntem olarak dikkat çekmektedir. Döner tamburlu kompostlaştırıcılar, mobil kompostlama için etkin ve yaygınlaşma olasılığı yüksek bir tekniktir. Bu sistem; silindirik ve uzun ekseni yere paralel yapıda, merkezinde dönen tambur içinde materyal akışının gerçekleştiği bir reaktör sistemidir. Tambur içerisindeki atık materyal eşit, kontrollü yüksek ortam sıcaklığında ve hızlı bir şekilde kompostlaştırılmaktadır. Tambur içerisindeki materyal, devamlı ya da tercihen seçilen aralıklarla yavaş bir şekilde döndürülmekte, tamburun dönü hareketiyle materyal silindir içerisinde ilerletilmektedir. Temiz hava, ürün çıkış yönünden giriş yönüne doğru yönlendirilmekte, kirli hava ürün giriş yönünden dışarı atılmaktadır. Sistemin en büyük avantajı, kompostlaştırma süresinin diğer yöntemlere kıyasla kısa olmasıdır. Döner tambur, homojen bir ürün elde etmek için kompostun havalandırılmasını ve karıştırılmasını sağlamakta, çıkan ürün stabil, homojen ve kaliteli olmaktadır. Sistemden ortama koku ve sızıntı suyu çıkışı gerçekleşmemektedir (Soyöz, 2018).

Kompostlama sürecindeki sorunlardan biri, sürecin tamamlanması için gereken sürenin uzun olmasıdır. Örneğin, küçük ölçekli yığın kompostlama yöntemi kullanılarak kompost üretilmesi üç ila dört ay sürmektedir. Bu sürecin hızlandırılması için kullanılan yöntemlerden biri biyoaktivatör kullanımıdır. Nitekim, Sadik vd. (2010) tarafından yapılan çalışmada, hayvan gübresi (bıldırcın, keçi ve koyun gübresi), bitkisel atıklar (hurma ağaçları, narenciye ve zeytin ağaçları budama atıkları) ve yeşil peyzaj çimlerini sırasıyla $\% 50, \% 25$ ve \% 25 oranlarında karıştırarak yığın oluşturmuş ve BZT ${ }^{\circledR}$ Compost Activator ilave etmiştir. Aynı bileşen ile oluşturulan biyoaktivatörsüz ikinci yığın, kontrol olarak ele alınmıştır. Sonuç olarak, BZT®Compost Activator ilavesinin kompostlama işlemini biyoaktivatör içermeyen yığına göre hızlandırarak 68-180 günden (geleneksel kompostlama yöntemine göre) 35 güne düşürdüğü tespit edilmiştir. Diğer taraftan, Saravanan vd. (2013) gıda atıklarının kompostlama sürecinin Etkili Mikroorganizma (EM) kullanımı ile 2 aydan 45 güne düşürüldüğü bildirmiştir.

Bu çalışmanın temel amacı, nar kabuklarının egzoz gazı geri dönüşümlü döner tambur kompostlaştırma sistemini kullanarak kompostlaştırılmasında bioaktivatörün (BIOKOR BZT ${ }^{\circledR}$ Compost Aktivatör) etkisini belirlemektir.

\section{Materyal ve Metot}

\subsection{Materyal}

Nar meyvesinin meyve suyuna işlenmesinden sonra atık olarak çıkan nar kabuklarının kompostlaştırmayla ilişkili analiz sonuçları Tablo 1'de verilmiştir. Çalışmada kullanılan nar kabukları Erzincan ilinde faaliyet gösteren Tunay Gıda meyve işleme tesisinden temin edilmiş, kısmi kurutma ile su içeriği azaltılmış ve parçalanmıştır.

\section{Tablo 1. Atık nar kabuğunun fiziko-kimyasal analiz sonuçları}

\begin{tabular}{ll}
\hline \multicolumn{1}{c}{ Parametre } & Nar kabuğu \\
\hline Nem içeriği (yaş baz, \%) & 60.00 \\
Organik madde içeriği ( \%) & 92.62 \\
pH & 5.35 \\
Elektriksel iletkenlik (EC, dS/m) & 2.40 \\
Toplam karbon (C, \%) & 41.49 \\
Toplam azot (N, \%) & 1.35 \\
C/N & 30.73 \\
\hline
\end{tabular}

Egzoz gazı geri dönüşümlü döner tambur kompostlama sistemi; uzunluğu $105 \mathrm{~cm}$, çapı $82 \mathrm{~cm}$ ve et kalınlığı $10 \mathrm{~cm}$ özel koruge silindirik boru malzemeden imal edilmiştir (Şekil 1). Silindirin hacmi $0.38 \mathrm{~m}^{3}$ 'tür. Döner tambur kompostlama sisteminin 1sı izolasyonu, $5 \mathrm{~cm}$ kalınlığındaki taş yünü ile yapılmıştır. Döner tambur, $0.55 \mathrm{~kW}$ 'lık bir elektrik motoru ile tahrik edilmiştir. Elektrik motoruna redüktör (10 devir/dakika) bağlıdır. Tambur gövdesi dönüş hareketi $1 \mathrm{~min}^{-1}$ olacak şekilde mekanik olarak ayarlanmıştır. Döner tambura bir havalandırma fanı $(0.55 \mathrm{~kW}$ ve $2800 \mathrm{~d} / \mathrm{d})$ ile hava basılmıştır. Tamburun içinde havanın dağıtımı, iç yüzey boyunca yerleştirilmiş her biri $2.54 \mathrm{~cm}$ çapında beş adet PPRC boru kullanılarak gerçekleştirilmiştir. Döner tamburdan çıkan egzoz havası, ortam havasıyla karıştırılıp egzoz gazı geri dönüşüm sisteminden yararlanılarak tekrar tambur içerisine yönlendirilmiștir. Döner tambur, havalandırma kontrolü ve egzoz gazı geri dönüşüm oranının karar parametresi olarak kullanılması PLC sistemiyle gerçekleştirilmiştir. Dış ortam ve tambur içi kompost sicaklığ 1 J tipi 1sıl çiftler kullanılarak ölçülmüştür (dakikada bir). $\mathrm{CO}_{2}$ konsantrasyonu, $\mathrm{CO}_{2}$ sensörü (GMT220, Vaisala), kompost kütlesinin zamana bağlı değişimi ise, dönen tambur çerçevesinin altına yerleştirilmiş dört adet yük hücresiyle (load cells) oluşturulan tambur tartı sisteminden yararlanılarak ölçülmüştür. 
Denemelerde, nar kabuklarının dışında herhangi bir organik materyal kullanılmamış, nar kabuklarının anılan sistemde kompostlaştırılmasında tek bir karışım denenmiştir. Bunun yanında, pH dengesi için karışıma kuru ağırlık bazında \%6.59 oranında sönmemiş kireç $(\mathrm{CaO})$ eklenmiştir. Nar kabuğunun $\mathrm{C} / \mathrm{N}$ oranı \%30.73 olarak belirlenmiştir ve bu oran ideal kompostlaştırma oranı civarındadır. Çalışmada, biyoaktivatör olarak BIOKOR BZT®Compost Aktivatör'ü kullanılmıştır.

Çalışmada, biyoaktivatör olarak BIOKOR BZT®Compost Aktivatör'ü kullanılmış olup Design Group Danışmanlık Hizmetleri San. ve Tic. A.Ş. tarafından temin edilmiştir. Biyoaktivatör, peynir altı suyu bazlı bir taşıyıcıdaki mikroorganizmaların (vejetatif ve spor formları) ve enzimlerin bir karışımıdır. Türler Bacillus sp. ve Lactobacillus sp. cinsindendir. Enzimler, mikroorganizmalar için destekleyici olarak ilave edilmiştir. Biyoaktivatör; $100 \mathrm{~kg}$ kuru maddeye 25 gr aktivatör suda çözündürülerek spring yöntemiyle karışımlara ilave edilmiştir. Denemeler, biyoaktivatörlü (Deneme-1) ve biyoaktivatörsüz (Deneme-2) olmak üzere 2 aşamada yürütülmüştür. Deneme süresince, sıcaklık, $\mathrm{CO}_{2}$ konsantrasyonu ve ağırlık ölçümleri yapıllmıştır.

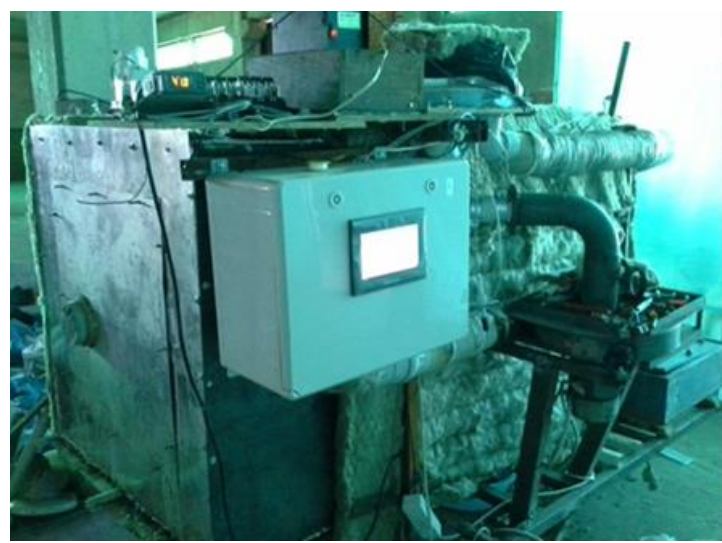

Şekil 1. Egzoz gazl geri dönüşümlü döner tambur kompostlaştırma sistemi

\subsection{Metot}

Denemeler süresince, kompost nem içeriği, organik madde içeriği, $\mathrm{pH}$, elektriksel iletkenlik $(\mathrm{EC}), \mathrm{C}, \mathrm{N}$ ve $\mathrm{C} / \mathrm{N}$ oranı değerleri takip edilmiştir.

Numunelerin nem içeriği $70 \pm 5^{\circ} \mathrm{C}$ 'de 3 gün süren kurutma sonucunda, organik madde içeriği ise $550{ }^{\circ} \mathrm{C}$ 'de ABD Tarım Bakanlığı ve ABD Kompostlama Konseyi tarafindan önerilen yönteme göre belirlenmiştir (TMECC, 2002). Numunelerin $\mathrm{pH}$ ve EC değerlerinin belirlenmesinde; 1:10 (w/v) katı: su oranında 20 dakika boyunca $180 \mathrm{~min}^{-1}$ devir altında çalkalama yapılıp ekstrakte elde edilmiş, $\mathrm{pH}$ ve EC metreler kullanılmıştır (Model
WTW pH 720 ve WTW Multi 340i. Toplam C ve N içerikleri, elemental analizör (Vario MACRO CN Elemental analizör) kullanılarak ölçülmüştür.

\section{Araştırma Sonuçları ve Tartışma}

\subsection{Kompost Sıcaklığı Değişimi}

Kompostlaştırılan materyal içerisindeki sıcaklık değişimi izlenerek sürecin hedeflenen doğrultuda ilerleyip ilerlemediği kontrol edilmektedir (Sadef vd., 2014; Villar vd., 2016). Kompostlama kütlesi içindeki sıcaklık, biyolojik işlemlerin gerçekleştiği hızı belirlerken (Hassen vd., 2001) aynı zamanda mezofilik ve termofilik bozunma evrelerinde aktif olan mikrobiyal popülasyonların varlığı konusunda en iyi göstergedir (Bosco vd., 2018). Çalışmada kompost materyal yığın içi sıcaklık ölçümleri 12 gün boyunca yapılmıştır. Kompostlaştırma işleminde sıcaklık, organik maddenin mikrobiyolojik olarak parçalanması sonucu yükselmiştir (Kadir vd., 2017). Mezofilik dönem; biyoaktivatörlü ve biyoaktivatörsüz reaktörlerde yaklaşık olarak sırasıyla 4. ve 1.5 günde başlamıştır. Termofilik faz ise (> $45^{\circ} \mathrm{C}$ ) Şekil 2 'de görüldügü üzere, biyoaktivatörlü reaktörde bulunan karışımda 4. günden sonra, biyoaktivatörsüz reaktörde bulunan karışımda ise 2. günden sonra gözlenmiştir. $55^{\circ} \mathrm{C}$ olarak en yüksek sicaklık değerine, biyoaktivatörlü ve biyoaktivatörsüz reaktörlerde sırasıyla, 6 . ve 2 . günde ulaşılmıştır.

Kompost Tebliği Ek-2 listesinde bulunan "kompost kalite parametreleri” tablosunda yı̆̆ının hijyen değerleri açısından tebliğe uygunluğu için kesintisiz bir şekilde $55^{\circ} \mathrm{C}$ 'de 2 hafta, $60{ }^{\circ} \mathrm{C}$ 'de ise 1 hafta süresince işlem görmüş olması gerektiği belirtilmektedir. Ancak, İslam vd., (2016) ve Flynn ve Wood, (1996) tarafından yapılan çalışmalarda, malzemenin sterilizasyon verimliliği değerlendirilirken yığının en az 3 gün boyunca $55{ }^{\circ}$ C'nin üzerindeki sıcaklıklarda işlem görmesinin yeterli olacağı bildirilmiştir. Şekil 2 incelendiğinde biyoaktivatörlü reaktörün $55{ }^{\circ} \mathrm{C}$ sicaklığa 6 . günde ulaştığ 1 ve bu sicaklığ yaklaşık 0.25 gün koruyabildiği anlaşılmaktadır. Biyoaktivatörsüz reaktör ise, $60^{\circ} \mathrm{C}$ sıcaklığa ulaşmış ancak bu sıcaklığı yaklaşık 1.5 gün ve $55^{\circ} \mathrm{C}$ 'nin üzerindeki sıcaklığını ise sadece 2 gün koruyabilmiştir. Bu nedenle hem Kompost tebliği hem de yapılan çalışmalara göre her iki yığının da stabilizasyon sıcaklık değerlerini gerektiği kadar koruyamadığı belirlenmiştir. Biyoaktivatörsüz reaktörün sıcaklık azalışı yaklaşık olarak 8 gün devam etmiştir. Bu değer, biyoaktivatörlü reaktöre kıyasla daha uzundur. Her iki reaktör de $30^{\circ} \mathrm{C}$ civarına kadar soğumuştur.

\section{2. $\mathrm{CO}_{2}$ Konsantrasyonu Değişimi}

Kompostlaştırma işlemi sırasında $\mathrm{CO}_{2}$ çıkışı, mikrobiyal popülasyon aktivitesinin bir göstergesidir (Henry ve Harrison, 1996; Luiza vd., 2014; Ojo vd., 2018). 

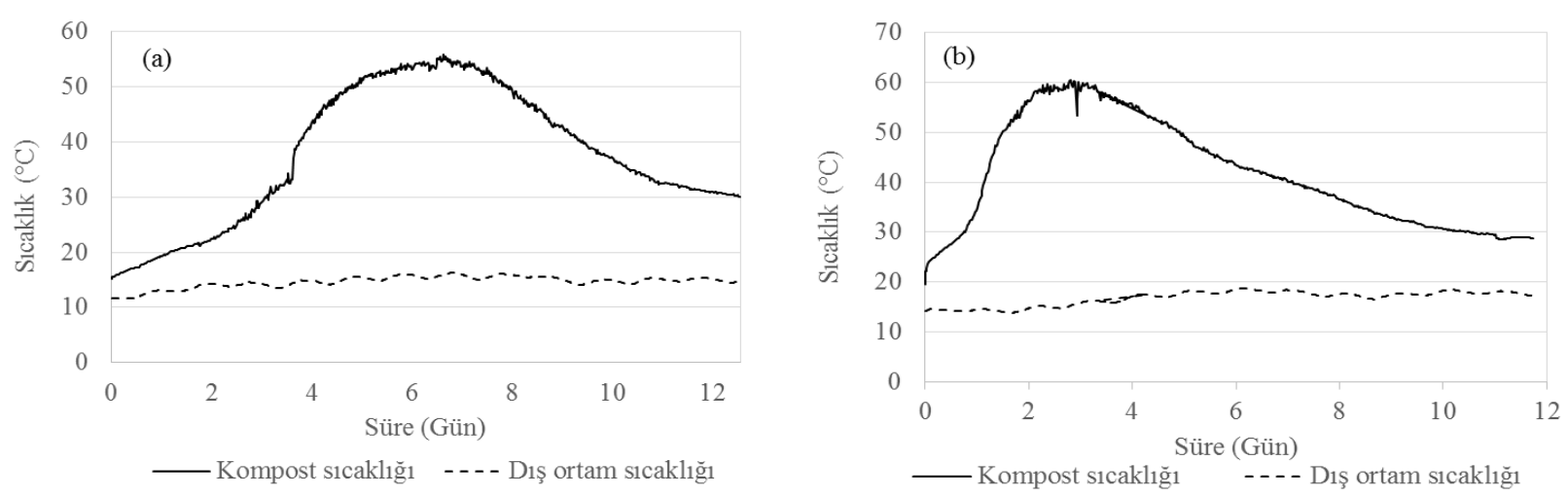

Şekil 2. Kompost sıcaklığı değişimi (a: Biyoaktivatörlü, b: Biyoaktivatörsüz)

Şekil 3 incelendiğinde, biyoaktivatörlü reaktörde $\mathrm{CO}_{2}$ çıkışının, sıcaklık artışında gözlendiği gibi, 4. günde en yüksek seviyeye ulaştığ 1 ve ardından azalarak \%4 civarına kadar düştüğü belirlenmiştir. Biyoaktivatörsüz reaktörde ise 2. güne kadar artan oranda $\mathrm{CO}_{2}$ çıkışı ölçülmüş denemenin sonuna doğru salınımın sabitlendiği ve diğer reaktörde olduğu gibi $\% 4$ civarına indiği gözlenmiştir. Bu artış ve azalışların kompostlamada görev yapan mikroorganizmaların sayısıyla orantılı olduğu bilinmekle birlikte,

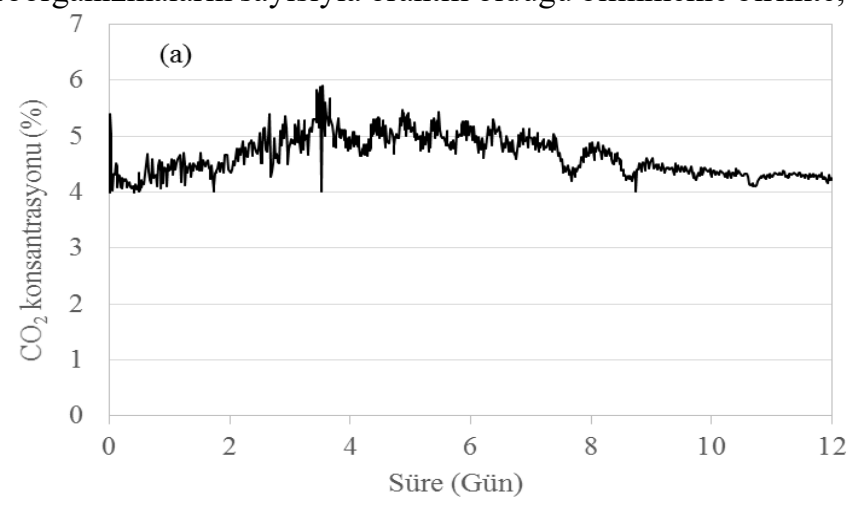

(Henry ve Harrison, 1996; Luiza vd., 2014; Ojo vd., 2018), bu duruma gerekçe olarak, bakterilerin substrat varlığında hızlı üremeleri ve bu süreçte hem sıcaklığın hem de $\mathrm{CO}_{2}$ salınımlarında artış oluştuğu gösterilebilir. Diğer yandan, reaktörlerdeki $\mathrm{CO}_{2}$ oranlarının \%4'ün altına düşmemesinin, karışım içerisinde bakteri faaliyetlerinin devam ettiğinin bir göstergesi olduğu söylenebilir.

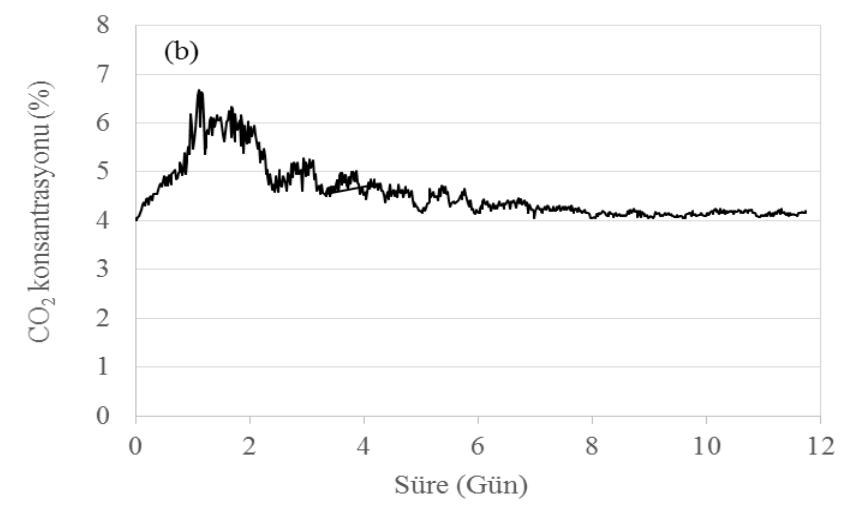

Şekil 3. $\mathrm{CO}_{2}$ Konsantrasyonunun süreye bağlı değişimi (a: Biyoaktivatörlü, b: Biyoaktivatörsüz)

\subsection{Kompost Nemi Değişimi}

Kompostlaştırılan karışımın nem içeriği, organik atıkların mikroorganizmalar tarafından ayrıştırılması için önemli bir parametredir. Aktif kompostlaştırma sırasında sıcaklığın yükselmesiyle buharlaşma artmakta ve yığın içi nem içeriğinde düşüş meydana gelmektedir (Muntjeer vd., 2014). Buna ilaveten, reaktörlerdeki nem içeriği değişimleri; organik maddenin ayrışması, sızıntı suyu oluşumu ve yoğuşma gibi nedenlerle meydana gelmektedir (Şevik vd., 2018b). Kompostlaştırma işleminden sonra, olgunlaşma aşamasında da yığın içi nem içeriği ölçümleri sürdürülmüştür. Yapılan nem içeriği ölçüm sonuçları Şekil 4 'te verilmiştir. Şekil 4 incelendiğinde, 12 günlük kompostlaştırma süresince her iki reaktör içerisindeki yığın nem içeriği değişimi görülmektedir. Kompostlaştırma işlemi sonunda her iki reaktörde bulunan kompost karışımlarının nem içeriklerinin birbirine yakın değerlerde olduğu belirlenmiştir. Biyoaktivatör ilaveli reaktörden çıkan karışımın nemi, olgunlaşma aşamasında bir süre daha azalmış daha sonra bir miktar artış göstermiştir. Buna karşın, biyoaktivatör ilavesiz reaktörde tersine nem içeriği 30. güne kadar artış göstermiş sonrasında azalarak \%44.61 seviyelerine kadar inmiştir. Reaktörlerde kompostlaştırma aşamasındaki nem azalışlarının sebebi; yüksek düzeyde ayrışmanın bir sonucu olarak, metabolik ısıl enerji üretimi ve buna bağlı olarak buharlaşmadaki artış olarak gösterilebilir. Biyoaktivatör ilaveli (Deneme-1) numunelerin olgunlaşma aşamasında nem içeriği azalışının sürmesi, kompostlaştırma işleminin henüz tamamlanmadığını diğer bir ifadeyle, kompost karışımının sıcaklı̆̆ının henüz tam olarak düşmediğinin göstergesi olarak değerlendirilebilir. Aynı reaktör için nem içeriği düşüşünün hemen ardından tekrar artışın oluşması da Muntjeer vd., (2014) belirttiği gibi kompostun olgunlaştırıldığı ortam havasının nem içeriği ile ilişkilendirilebilir. Biyoaktivatör ilavesiz (Deneme-2) reaktörde nem içeriği değerinin olgunlaşma aşamasında artışının nedeni; olgunlaşmanın ilk aşamasında, kompostlaşan karışımın ortam nem içeriğiyle açıklanabilir. Sonrasında nem içeriğindeki azalışının, ortam sıcaklığındaki artış nedeniyle gerçekleştiği sonucuna varılabilir. 


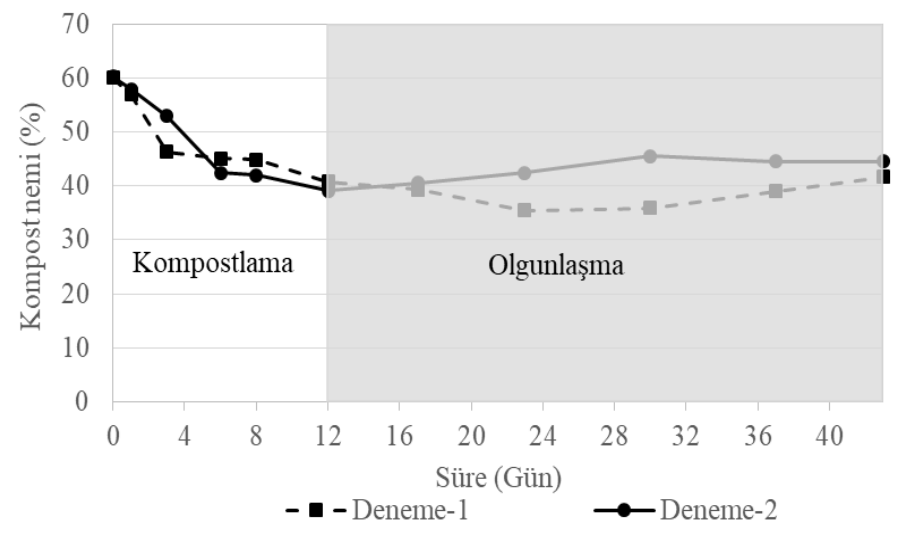

Şekil 4. Kompost neminin süreye bağlı değişimi

\subsection{Kompost Organik Madde Değişimi}

Organik maddenin kolay ayrışabilir kısmının mikroorganizmalar tarafindan tüketilmesi sonucu, kompost sıcaklığı hızlı bir şekilde yükselmektedir (Şekil 5) (Muntjeer vd., 2014). Diğer bir ifadeyle, birim kompost materyal hacmi içerisindeki organik madde azalmasının maksimum olduğu dönem, kompostlaşma aşamasında sicaklı̆ğın en yüksek olduğu aralığa denk gelmektedir. Kompostlaşma aşamasında organik madde miktarındaki, nispeten fazla olan azalış, olgunlaşma aşamasında da (Deneme-1'deki süreçte gözlendiği gibi) devam etmiştir. Biyoaktivatör ilavesiz reaktörde (Deneme-2) sıcaklıkların maksimum değerlere ulaştığı 2-4 gün aralığında, organik maddelerin yüksek miktarda azalması, Muntjeer vd., (2014) tarafindan öne sürülen, 'sıcaklığın artmasıyla, organik madde mikroorganizmalar tarafindan daha kolay tüketilir' yaklaşımını desteklemektedir. Biyoaktivatör ilaveli denemede organik madde miktarındaki azalmanın daha orantılı ve düzgün bir eğri şeklinde gerçekleştiği , biyoaktivatör ilavesiz denemede ise yüksek miktarlı organik madde değişiminin kısa sürede gerçekleştiği gözlenmiştir (Muntjeer vd., 2014).

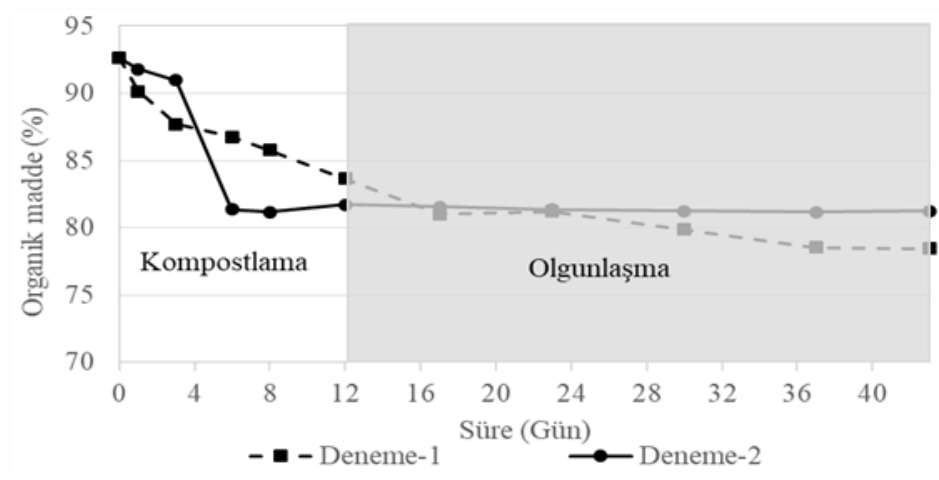

Şekil 5. Kompostlaşan materyal organik madde içeriğinin süreye bağlı değişimi

\subsection{Kompost C/N Oranının Değişimi}

$\mathrm{C} / \mathrm{N}$ oranı kompostlaştırma açısından önemli bir parametredir. Genel bir yaklaşım ile $\mathrm{C} / \mathrm{N}<20$ olduğunda $\mathrm{N}$, basit inorganik azot formlarına dönüşmekte (mineralizasyon); buna karşın, C/N $>20$ olduğunda ise mineral azot formları canlı organizma dokularına girmekte, karmaşık bileşikler içinde organik olarak tutulma olayı (asimilasyon veya azotimmobilizasyonu) gerçekleşmektedir (Truong ve Marchner, 2018). Şekil 6 incelendiğinde; biyoaktivatör ilaveli reaktörde N- immobilizasyonunun kompostlaşma süresi olan 12 gün boyunca devam ettiği ve olgunlaşma süreciyle birlikte mineralizasyon sürecinin başladığı ifade edilebilir. Benzer durumun, biyoaktivatör ilavesiz reaktör için 8 . gün itibarıly gerçekleştiği söylenebilir. Biyoaktivatör ilaveli reaktörden elde edilen $\mathrm{C} / \mathrm{N}$ değerleri, Truong ve Marschner (2018) tarafindan elde edilen sonuçlarla uyumludur. Sonuçlarda, biyoaktivatör ilavesiz reaktörde sıcaklığın maksimum $60{ }^{\circ} \mathrm{C}$ olarak gerçekleştiği, üçüncü gün yaklaşık $45{ }^{\circ} \mathrm{C}$ 'ye düştüğü belirlenmiştir. Altıncı günün $\mathrm{C} / \mathrm{N}$ oranları kıyaslandığında, yaklaşık $\% 18^{\prime}$ lik bir $\mathrm{C} / \mathrm{N}$ oranı azalışı gözlenirken, sıcaklığın $45^{\circ} \mathrm{C}$ 'den $35^{\circ} \mathrm{C}$ ye düştüğü sekizinci günde aynı değer $\% 18.5$ oranında azalma göstermiştir.

Kompostlaşma işlemi boyunca meydana gelen, $\mathrm{C}$ ve $\mathrm{N}$ kayıpları, kompost kalitesi üzerinde önemli düzeyde etkilidir (Larney vd., 2006). İlk ölçümde biyoaktivatör ilavesiz reaktördeki numunelerin $\mathrm{C} / \mathrm{N}$ oranı, biyoaktivatör ilaveli reaktöre kıyasla daha hızlı bir azalış göstermiştir. Benzer azalış, biyoaktivatör ilaveli reaktörde ikinci ölçümde gözlenmiştir. Diğer bütün ölçümlerde dalgalanmalar gözlenmiş ve sonuç olarak onuncu ölçümde biyoaktivatör ilaveli ve ilavesiz reaktörlerde $\mathrm{C} / \mathrm{N}$ değeri sırasıyla 15.01 ve 18.45 olarak belirlenmiştir. Sonuçta; başlangıç aşamasında aynı $\mathrm{C} / \mathrm{N}$ oranına sahip olan iki karışımın, aktif kompostlaşma ve olgunlaşma süreçlerinin ardından gerçekleşen $\mathrm{C} / \mathrm{N}$ oranındaki azalma değerleri, biyoaktivatör ilaveli ve ilavesiz reaktörler için sırasıyla $\% 44.06$ ve $\% \quad 31.18$ olarak gerçekleşmiş̧ir. Kompostlaşma ve olgunlaşma süreci sonunda biyoaktivatör ilaveli ve ilavesiz reaktörlerde meydana gelen organik madde kayıpları sırasıyla, \%59.24-\%14.63 ve \%64.32\%2.04 olarak belirlenmiştir. Bu değerler göz önüne alındığında kompostlaşma aşamasında, biyoaktivatör ilavesiz reaktörde $\mathrm{N}$ kaybının, biyoaktivatör ilaveli reaktöre kıyasla daha fazla miktarda gerçekleştiği, buna karşın, olgunlaşma sonunda biyoaktivatör ilaveli reaktörde biyoaktivatör ilavesiz reaktöre kıyasla daha fazla olduğu ortaya çıkmaktadır. Zhang vd., (2019) tarafindan yürütülen ve farklı $\mathrm{C} / \mathrm{N}$ oranlarının $(20: 1,25: 1,30: 1)$ denendiği çalışmada belirlenen organik madde kayıplarının sirasılya; $\% 22.39, \quad \% 21.38$ ve $\% 21.49$ olarak gerçekleştiği vurgulanmıştır. Mevcut çalışmada elde edilen organik madde kayıplarının kompostlama süreci ve olgunlaşma süreci sonunda sırasıyla, biyoaktivatörlü reaktörde $\% 59.24$ ve $\% 14.63$, biyoaktivatörsüz reaktörde $\% 64.32$ ve $\% 2.04$ olarak bulunması organik madde kayıpları açısından biyoaktivatörlü reaktörde olgunlaşma aşamasında, biyoaktivatörsüz reaktörde ise kompostlama aşamasında $\mathrm{C} / \mathrm{N}$ ve organik madde kayıpları açısından başarılı olduğu söylenebilir.

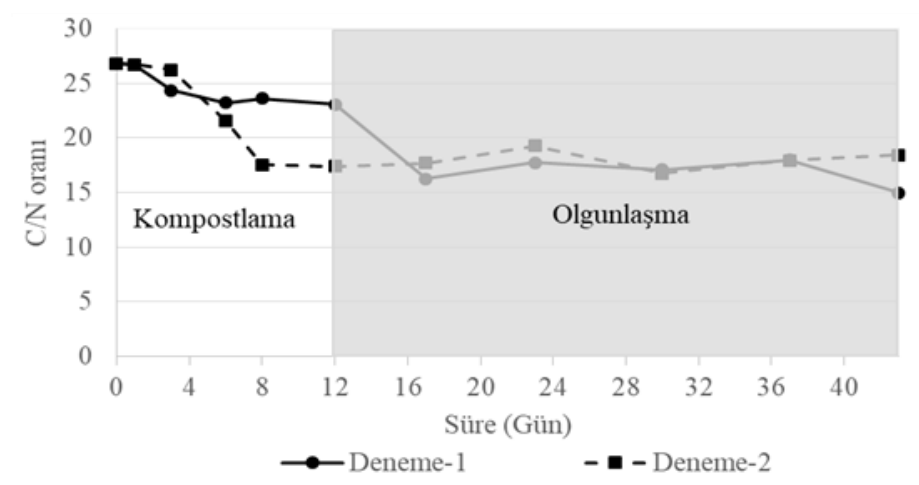

Şekil 6. Kompost materyali C/N oranının süreye bağlı değişimi 


\subsection{Kompost EC Değerinin Değişimi}

Genel olarak EC değeri, ayrışma sırasında nitrat ve fosfat gibi çözülebilir tuzların kompostlaşma ortamına salınması sonucunda artmaktadır. Buna karşın, amonyağın uçucu forma geçmesi ve mineral tuzların sızması nedeniyle EC değerinde azalma gerçekleşmektedir (Lazcano vd., 2008; Lui ve Price, 2011). Biyoaktivatör ilaveli reaktörde altıncı günde gerçekleşen EC artışının ve daha sonraki azalmanın nedeni yukarıdaki gerekçelerle açıklanabilir (Lazcano vd., 2008; Lui ve Price, 2011). Benzer şekilde; biyoaktivatör ilavesiz reaktörde altıncı günde (Şekil 7) gözlenen ani düşüşün sebebinin, amonyağın uçucu hale

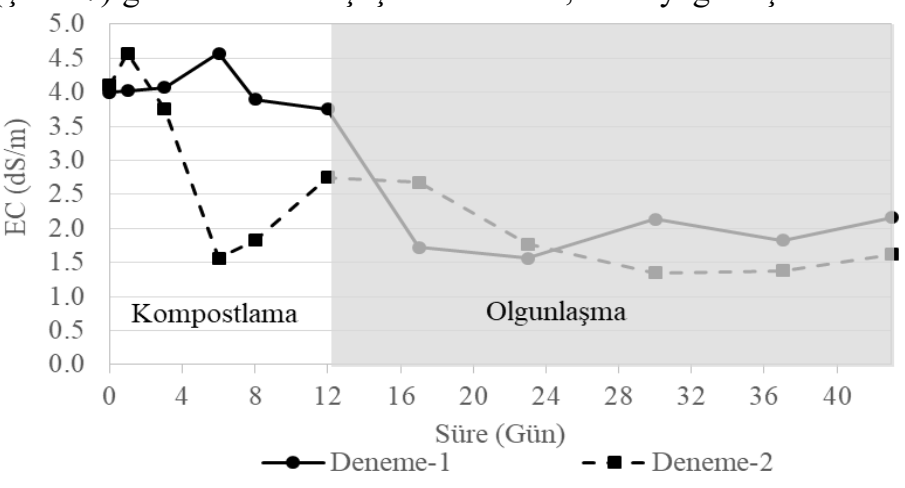

Şekil 7. Kompost EC değerinin süreye bă̆lı değişimi

\subsection{Kompost (kompost materyali) pH Değerinin Değişimi}

Kompostlaştırma işleminin ilk haftalarında organik madde ayrışması sonucunda amonyum oluşumuna ve amonyağın çözünmesine bağlı olarak, kompost materyali içerisindeki $\mathrm{pH}$ değerinde değişimler belirlenmiştir (He vd., 2018; Wang vd., 2016; Agnolucci vd., 2013). Şekil 8 incelendiğinde, $\mathrm{N}$ içeren organik bileşiklerin (proteinler ve amino asitler) amonyum içerisindeki hızlı mineralizasyonu ve birikmesi nedeniyle biyoaktivatör ilaveli reaktörün $\mathrm{pH}$ değerlerinde düzenli bir artış, biyoaktivatör ilavesiz reaktörde ise kompostlaşmanın üçüncü gününde $\mathrm{pH}$ değerinde bir azalma tespit edilmiştir. Daha sonraki süreçte, her iki reaktörde $\mathrm{pH}$ değerleri on yedinci güne kadar artmaya devam etmiştir. Başlangıç $\mathrm{pH}$ değerleri farklı olmasına rağmen, her iki kompost numunesinin, olgunlaşma süresi ve olgunlaşma sonrasında birbirine yakın ve optimum değerler olarak bilinen $\mathrm{pH}$ 6-9 aralığında gerçekleşmiştir. $\mathrm{Bu}$ sonuç, numunelerin ideal bir $\mathrm{pH}$ değişim eğiliminde olduğunu göstermektedir (Rykeboer vd., 2003; Liu vd., 2011; Zhang vd., 2018; Zhang vd. 2019). Sonuç olarak, biyoaktivatör kullanımının $\mathrm{pH}$ değerleri değişiminde etkisinin olmadığı belirlenmiştir.

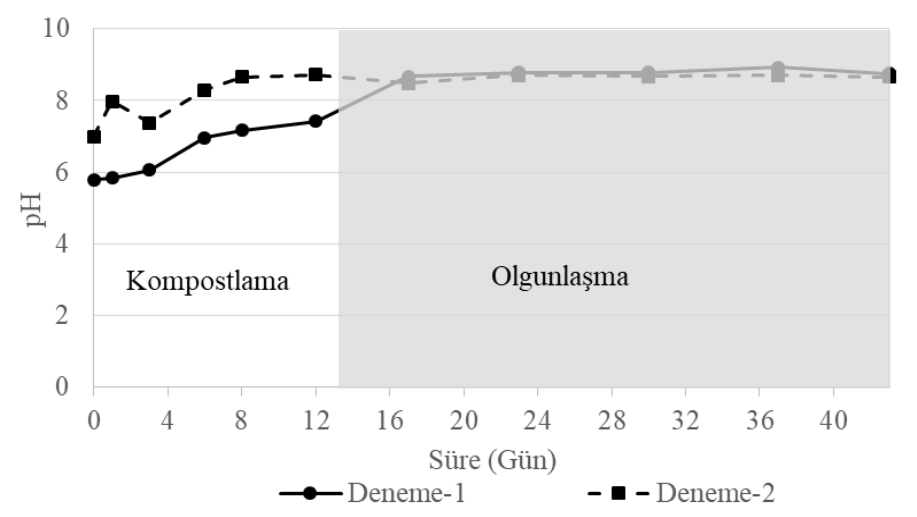

Şekil 8. Kompost pH değerinin süreye bă̆lı değişimi gelmesi ve mineral tuzların sızması olabileceği ifade edilebilir (Lazcano vd., 2008; Lui ve Price, 2011). EC değerlerinin; biyoaktivatör ilaveli reaktörde biyoaktivatör ilavesiz reaktöre kıyasla yüksek değerlerde seyretmesi, biyoaktivatörün etkisiyle kompost materyali bünyesindeki iyonların serbest kalma miktarını arttırmasıyla açıklanabilir. EC değerlerinin biyoaktivatör ilaveli ve ilavesiz reaktörlerde sırasıyla $2.16 \mathrm{dS} / \mathrm{m}$ $(\mathrm{mS} / \mathrm{cm})$ ve1.62 dS/m $(\mathrm{mS} / \mathrm{cm} \leq 4 \mathrm{mS} / \mathrm{cm}$ olarak belirlenmiş olması, kompostların EC bakımından olgunluğa ulaştığını ve toprağa güvenle uygulanabileceğini göstermektedir (Awasthi vd., 2017).

\section{Sonuç}

Narın işlenmesi sonucunda ortaya çıkan nar kabuğu atıkları, $0.38 \mathrm{~m}^{3}$ 'lük hacme sahip egzoz gazı geri dönüşümlü otomatik kontrollü döner tambur sisteminde kompostlaştırılmıştır. Çalışmanın amacı; nar kabuklarının döner tamburda kompostlaştırma işleminde, bioaktivatör (BIOKOR BZT ${ }^{\circledR}$ Compost Aktivatör) etkisinin belirlenmesi olarak seçilmiştir. Deneme süresince, kompostlaşma performans parametreleri olarak bilinen; sicaklık, $\mathrm{CO}_{2}$ konsantrasyonu, kompost materyal nemi, organik madde içeriği, $\mathrm{pH}$ düzeyi, elektriksel iletkenlik değeri ve $\mathrm{C} / \mathrm{N}$ oranı ölçümlerle belirlenmiştir. Kompostlaşma ve olgunlaşma süreçleri sırasıyla, 12 ve 31 gün olarak tespit edilmiştir. Elde edilen sonuçlara göre; performans parametreleri açısından, biyoaktivatör ilaveli (Deneme-1) kompostlaştırmanın bir fark yaratmadığ belirlenmiştir. Diğer taraftan, kompostun daha hızlı olgunlaşması amacıyla biyoaktivatörün karışım içerisine kompost olgunlaşma süreci başlangıcında eklenmesi önerilmektedir.

\section{Teşekkür}

Bu çalışmanın yürütülmesinde destek veren; Cenk Soyöz MTF Makine Kimya Otomasyon, Tunay Gıda San. ve Tic. A.Ş ve Design Group Danışmanlık Hizmetleri San. ve Tic. A.Ş.'ye teşekkür ederiz.

\section{Kaynakça}

Agnolucci, M., Cristani, C., Battini, F., Palla, M., Cardelli, R., Saviozzi, A., Nuti, M. (2013). Microbially-enhanced composting of olive mill solid waste (wet husk): bacterial and fungal community dynamics at industrial pilot and farm level. Bioresource Technology, 34, 10-16.

Awasthi, M.K., Wang, Q., Chen, H., Wang, M., Rena, X., Zhao, J., Li, J., Guo, D., Li, D.S., Awasthi, S.K., Sun, X., Zhang, Z. (2017). Evaluation of biochar amended biosolids cocomposting to improve the nutrient transformation and its correlation as a function for the production of nutrient-rich compost, Bioresource Technology, 237, 156-166.

Bosco, T., C., D., Michels, R., N., Bertozzi, J., Junior, I., T., Hashimoto, E., M. (2018). The ideal frequency of temperature data collection in compostability experiments on domestic organic residues. Environmental Technology, 41(9), 1160-1166.

Flynn, P.R., Wood, C.W. (1996). Temperature and chemical changes during composting of broiler litter. Compost Science and Utilization, 4(3), 62-70.

Ghaly, A. E., and M. Alhattah. (2013). Drying poultry manure for pollution potential reduction and production of organic fertilizer. America Journal of Environmental Science, 9(2), 88-102. 
Hassen, A., Belguith, K., Jedidi, N., Cherif, A., Cherif, M., \& Boudabous, A. (2001). Microbial characterization during composting of municipal solid waste. Bioresource Technology, 80(3), 217-225.

He, P., Wei, S., Shao, L., \& Lü, F. (2018). Emission potential of volatile sulfur compounds (VSCs) and ammonia from sludge compost with different bio-stability under various oxygen levels. Waste Management, 73, 113-122.

Henry, C. L., and R. B. Harrison. (1996). Carbon Fraction in Compost and Compost Maturity Tests. In Soil organic matter: analysis and interpretation, ed. by F. R. Magdoff, M. A. Taabatabai and E. A. Harlon, 51-67. USA: SSA Special Publication.

Islam, M. K., Yaseen, T., Traversa, A., Kheder, M. B., Brunetti, G., \& Cocozza, C. (2016). Effects of the main extraction parameters on chemical and microbial characteristics of compost tea. Waste Management, 52, 62-68.

Kadir, A. A., N. W. Azhari, and Jamaludin, S. N. (2017). Evaluation of physical, chemical and heavy metal concentration of food waste composting. Web of Conference 103:5-14.

Kanat, G. \& Ergüven, G. Ö. (2020). Importance of Solid Waste Management on Composting, Problems and Proposed Solutions: The Case of Turkey. Avrupa Bilim ve Teknoloji Dergisi, (19), 66-71.

Larney, F. J., Sullivan, D. M., Buckley, K. E., \& Eghball, B. (2006). The role of composting in recycling manure nutrients. Canadian Journal of Soil Science, 86(4), 597-611.

Lazcano, C., Gómez-Brandón, M., \& Domínguez, J. (2008). Comparison of the effectiveness of composting and vermicomposting for the biological stabilization of cattle manure. Chemosphere, 72(7), 1013-1019.

Liu, D., Zhang, R., Wu, H., Xu, D., Tang, Z., Yu, G., Xu, Z., Shen, Q. (2011). Changes in biochemical and microbiological parameters during the period of rapid composting of dairy manure with rice chaff. Bioresource Technology, 102, 90409049.

Liu, K., Price, G.W. (2011). Evaluation of three composting systems for the management of spent coffee grounds. Bioresource Technology, 102, 7966-7974.

Luiza, R., M. Javares, and E. Nahas. (2014). Humic fractions of forest, pasture and maize crop soils resulting from microbial activity. Brazilian Journal of Microbiology 45(3), 963-69.

Muntjeer, A., Kazmi, AA., Ahmed, N. (2014). Study on effects of temperature, moisture and $\mathrm{pH}$ in degradation and degradation kinetics of aldrin, endosulfan, lindane pesticides during full-scale continuous rotary drum composting. Chemosphere, 102, 68-75.

Ojo, A., O., Taiwo, L., B., Adediran, J., A., Oyedele, A., O., Fademi, I., O., Uthman, A., C., O. (2018). Physical, Chemical and Biological Properties of an Accelerated Cassava Based Compost Prepared Using Different Ratios of Cassava Peels and Poultry Manure. Communications in Soil Science and Plant Analysis, 49(14), 1774-1786.

Ryckeboer, J., Mergaert, J., Vaes, K., Klammer, S., De Clercq, D., Coosemans, J., Insam, H., Swings, J. (2003). A survey of bacteria and fungi occurring during composting and selfheating processes. Annals of microbiology, 53(4), 349-410.

Sadef, Y., Poulsen, T. G., \& Bester, K. (2014). Impact of compost process temperature on organic micro-pollutant degradation. Science of the Total Environment, 494, 306-312.

Sadik, M. W., El Shaer, H. M., \& Yakot, H. M. (2010). Recycling of agriculture and animal farm wastes into compost using compost activator in Saudi Arabia. Journal of International Environmental Application and Science, 5(3), 397-403.

Saravanan, P., Kumar, S. S., \& Ajithan, C. (2013). Eco-friendly practice of utilization of food wastes. International Journal of Pharmaceutical Sciences Innovation, 2(1), 14-17.

Soyöz, C., (2018). Egzoz gazı geri dönüşümünün döner tambur kompostlama sistemine etkisi. Yüksek lisans tezi, Süleyman Demirel Üniversitesi, Isparta.

Şevik F., Tosun, İ., Ekinci, K. (2018a). Nar İşleme Atıklarının Özellikleri ve Bertaraf. Stratejilerinin Belirlenmesi. Uluslararası Marmara Fen Ve Sosyal Bilimler Kongresi, 23 25 Kasim 2018, Kocaeli.

Şevik, F., Tosun, İ., Ekinci, K. (2018b). The effect of FAS and C/N ratios on co-composting of sewage sludge, dairy manure and tomato stalks. Waste Management, 80, 450-456.

TMECC (2002). Test Methods for the Examination of Composting and Composts. Wayne Thompson, the US Composting Council, US Government Printing Office.

Truong, T.H.H., Marschner, P. (2018). Respiration, available N and microbial biomass $\mathrm{N}$ in soil amended with mixes of organic materials differing in $\mathrm{C} / \mathrm{N}$ ratio and decomposition stage. Geoderma, 319, 167-174.

Villar, I., Alves, D., Garrido, J. (2016). Evolution of microbial dynamics during the maturation phase of the composting of different types of waste. Waste Management, 54, 83-92.

Wang, Q., Wang, Z., Awasthi, M.K., Jiang, Y.H., Li, R.H., Ren, X.N., Zhao, J.C., Shen, F., Wang, M. J., Zhang, Z.Q. (2016). Evaluation of medical stone amendment for the reduction of nitrogen loss and bioavailability of heavy metals during pig manure composting. Bioresource Technology, 220, 297304.

Zhang, C.S., Xu, Y., Zhao, M.H., Rong, H.W., Zhang, K.F. (2018). Influence of inoculating white-rot fungi on organic matter transformations and mobility of heavy metals in sewage sludge based composting. Journal of Hazardous Materials, 344, 163-168.

Zhang, J., Bao, Y., Jiang, Y., Liu H. T., Xi, B. D., Wang, D. Q. (2019). Removal and dissipation pathway of typical fluoroquinolones in sewage sludge during aerobic composting. Waste Management, 95, 450-457. 